CZASOPISMO INŻYNIERII LA¿OWEJ, ŚRODOWISKA I ARCHITEKTURY JOURNAL OF CIVIL ENGINEERING, ENVIRONMENT AND ARCHITECTURE

JCEEA, t. XXXIV, z. 64 (4///17), październik-grudzień 2017, s. 425-434, DOI:10.7862/rb.2017.224

\author{
Katarzyna PIETRUCHA-URBANIK ${ }^{1}$ \\ Dominika SKOWROŃSKA ${ }^{2}$
}

\title{
APPROACH TO ANALYSE THE STATE OF HEALTH RESORTS BASE IN PODKARPACKIE PROVINCE
}

\begin{abstract}
In the work the approach to analyse the state of the health resorts located in Podkarpackie province was presented. The characteristics of Horyniec-Zdrój, Iwonicz-Zdrój, Polańczyk and Rymanów-Zdrój include a historical overview, description of climate, soil and water, health resort protection zones, available mineral water and medical raw materials and also description of performed treatments. The analysis was made on the basis of statistical data concerning the number of active centres, the number of patients, the number of performed treatments and the analysis of municipal infrastructure in the years 1995-2016. The analysis was performed on the basis of statistical data from Central Statistical Office. Additionally, the indicators of water supply infrastructure development and indicators of tourism development were calculated. The work is aimed at analysing all health resorts bases in the Podkarpackie province and determining which health resort develops best, where individual treatments are offered, as well as what medical raw materials caused that these places provide balneological treatments.
\end{abstract}

Keywords: health resort, characteristics of health resorts, municipal infrastructure, indicators of tourism development

\section{Introduction}

The increase in interest in natural medicine influenced the significant development of spa activities in Poland between the nineteenth and twentieth century, then after the end of the Second World War great emphasis was placed on the reconstruction and reactivation of damaged health resort bases. Areas of spas began to grow and gain publicity not only in the country but also in all of Europe.

Health resort treatment has become an alternative to pharmacology due to the lack of side effects and the length of the lasting effect of the action. Health resort tourism in Poland is a well-known brand in foreign markets, which results in

\footnotetext{
${ }^{1}$ Author for correspondence / autor do korespondencji: Katarzyna Pietrucha-Urbanik, Rzeszow University of Technology, Faculty of Civil, Environmental Engineering and Architecture, al. Powstańców Warszawy 6, 35-959 Rzeszów, Coresponding Author: e-mail: kpiet@prz.edu.pl

2 Dominika Skowrońska, Rzeszow University of Technology, Faculty of Civil, Environmental Engineering and Architecture, al. Powstańców Warszawy 6, 35-959 Rzeszów
} 
a very large national income. In addition to the well-known health resort bases in the country, there are also places in Podkarpackie that offered balneotherapy in the last century. In these places are also mineral springs that could be used inhealth resort therapies $[1,2]$. There are four health resort bases in the Podkarpackie Province. Health resort lowland Horyniec-Zdroj is located in the north-eastern part of the province, health resorts Iwonicz-Zdrój and Rymanów, foothill health resort, located in the southwestern part of the province and a highland resort Polańczyk is located in the south of the province in the Bieszczady mountains. Health resorts are known for natural mineral waters and healing, as well as from peat deposits that have been used for centuries in various balneological therapies. All four health resorts develop very dynamically, offering the patients various forms of health resort treatment and rest. All have a well-developed hotel, cultural, entertainment, recreational and gastronomic base $[3,4,5,6,7]$.

The work is aimed at analyzing all health resort bases in the Podkarpackie province and determining which of the health resorts develops best, where individual treatments are offered, as well as what natural healing resources caused that these places provide balneological treatments. The main source of data for writing this paper were data from Central Statistical Office for the years $1995-2016[8,9]$.

\section{Analysis of the health resort base of the Podkarpackie province}

\subsection{Mineral waters and natural healing resources of health resorts}

In all four health resorts of Podkarpackie Province are sources of natural mineral waters extracted for food and medicines.

From 1867 in Iwonicz-Zdrój the salt of Iwonice, Jodobromowa, is produced. It is obtained from natural mineral waters by traditional brewing methods. It is used in rheumatic diseases, gynecology, neurology, joint pain, skin and respiratory diseases in the form of baths, inhalations and wraps [10].

The Horyniec-Zdrój health resort includes, among others natural mineral waters originating from the Róża III and Róża IV boreholes, these are poorly mineralized sulphide waters in which the hydrogen sulphide content ranges between 24 and $50 \mathrm{mg} / \mathrm{dm}^{3}$. In Iwonicz-Zdrój, there are i.a. two wells, the first of them, Emma, is chloride-bicarbonate-sodium water with traces of iodine, boron, fluorine and bromine, and the other is chloride-bicarbonate-sodium water from the Lubatówka 14 well, with traces of iodine, bromine and boron. The Rymanów-Zdrój health resort has a total of eight wells, with chloridebicarbonate-sodium water, with traces of bromine, iodine and boron, also some water is bicarbonate-chloride-sodium, iodide, boron and fluoride.

A peat deposit "Podemszczyzna" is being exploited in Horyniec-Zdrój, it is so-called low peat-bog. It is used in the form of mud wraps and baths, as well as 
massages and iontophoresis. The Iwonicz-Zdrój health resort has been using peat bogs since 1879, when it was brought from the surrounding forests. Currently, the health resort uses peat mines extracted from the deposits in Wola Chorzelowska and Czarny Dunajec. These deposits are classified as low peatlands. They are used for mud compresses and baths. Polańczyk health resort does not have deposits of mud, but performs operations associated with its use. Rymanów-Zdrój extract mud from local lodges in the surrounding forests. It comes from low bogs containing iodine and traces of sulphates. It is used in the form of masks, full and partial wrappings, mud molds, galvanoborow and peloid iontophoresis $[11,12]$.

\subsection{Analysis of the health resorts base of the Podkarpackie Province}

Table 1 shows the number of actively operating sanatoriums and health resorts hospitals in the years 1995-2016.

In the years 1998-2007, we observe a decrease in the number of active health resort centers caused by the technical condition of buildings. Some have been restored and opened again, in addition to the presented centers in the Podkarpackie region, there are also three health resorts clinics. In every health resort, there are several or a dozen separate buildings that provide various forms of treatments. There are places such as health resorts, hospitals, clinics and other centers.

Table 2 presents the number of men and women, who stayed in the area of individual health resort facilities in 2010-2015.

Tab. 1. Total number of sanatoriums and health resort hospitals

Tab. 1. Całkowita liczba sanatoriów i szpitali uzdrowiskowych

\begin{tabular}{|l|c|c|c|c|c|c|c|c|c|c|c|}
\hline Year & 1995 & 1996 & 1997 & 1998 & 1999 & 2000 & 2001 & 2002 & 2003 & 2004 & 2005 \\
\hline Objects & 29 & 28 & 29 & 28 & 26 & 25 & 24 & 24 & 23 & 23 & 23 \\
\hline Year & 2006 & 2007 & 2008 & 2009 & 2010 & 2011 & 2012 & 2013 & 2014 & 2015 & 2016 \\
\hline Objects & 23 & 22 & 22 & 23 & 23 & 23 & 24 & 25 & 24 & 25 & 25 \\
\hline
\end{tabular}

Tab. 2. Summary of data on the number of women and men in health resorts

Tab. 2. Zestawienie danych dotyczących liczby kobiet i mężczyzn w ośrodkach uzdrowiskowych

\begin{tabular}{|l|l|r|r|r|r|r|r|r|}
\hline \multicolumn{2}{|l|}{ Health resort facilities } & 2010 & 2011 & 2012 & 2013 & 2014 & 2015 & 2016 \\
\hline \multirow{2}{*}{ Hospitals } & Man & 7321 & 5749 & 6030 & 4815 & 4871 & 5014 & 4942 \\
\cline { 2 - 9 } & Woman & 4214 & 5500 & 5720 & 5337 & 5275 & 5820 & 5857 \\
\hline \multirow{2}{*}{ Sanatoriums } & Man & 19936 & 19604 & 19314 & 19496 & 18181 & 19916 & 18986 \\
\cline { 2 - 9 } & Woman & 26087 & 27432 & 29354 & 28269 & 26807 & 27668 & 27480 \\
\hline $\begin{array}{l}\text { Health resort } \\
\text { physicians } \\
\text { and clinics }\end{array}$ & Man & 1051 & 992 & 782 & 502 & 731 & 612 & 786 \\
\cline { 2 - 9 } & Woman & 722 & 801 & 602 & 511 & 1100 & 1023 & 1271 \\
\hline
\end{tabular}


Table 3 shows the number of underage patients and the number of patients aged 65 or more residing in the health resort facilities in 2010-2015.

Tab. 3. Summary of data on the number of underage and people over 65 in health resorts

Tab. 3. Zestawienie danych dotyczących liczby osób niepełnoletnich i osób powyżej 65 lat w ośrodkach uzdrowiskowych

\begin{tabular}{|l|l|r|r|r|r|r|r|c|}
\hline Health resort facilities & 2010 & 2011 & 2012 & 2013 & 2014 & 2015 & 2016 \\
\hline \multirow{2}{*}{$\begin{array}{l}\text { Health resort } \\
\text { hospitals }\end{array}$} & $\begin{array}{l}\text { Less than } \\
18 \text { years }\end{array}$ & 1538 & 1631 & 1437 & 1372 & 1140 & 1204 & 1126 \\
\cline { 2 - 9 } & $\begin{array}{l}\text { More than } \\
65 \text { years }\end{array}$ & - & - & - & 2495 & 2314 & 2556 & 2761 \\
\hline \multirow{2}{*}{$\begin{array}{l}\text { Health resort } \\
\text { sanatoriums }\end{array}$} & $\begin{array}{l}\text { Less than } \\
18 \text { years }\end{array}$ & 1775 & 2020 & 1552 & 1727 & 1667 & 1548 & 1676 \\
\cline { 2 - 9 } & $\begin{array}{l}\text { More than } \\
65 \text { years }\end{array}$ & - & - & - & 13635 & 10424 & 11530 & 12704 \\
\hline
\end{tabular}

The number of people under the age of 18 remains constant in hospitals and sanatoriums as well as in health resort institutions. A vast minority are treated in health clinics. The same situation is with people over 65 , the vast majority are treated in hospitals, sanatoriums and health resorts institutions. Also the stationary and outpatient treatment mode were taken into account. In the stationary mode, the majority of patients are treated, as many as 60 thousand a year in sanatoriums and health resort hospitals, and 10 thousand a year in health resort institutions. In turn, outpatient treatment covers 2,5 thousand patients in sanatoria and health resort hospitals and 4 thousand patients are treated in health resort institutions.

\subsection{Medical treatments used in health resorts of Podkarpackie province}

Depending on the possibilities, different health resorts offer various balneological treatments. It is influenced by geographical location, local climate, access to natural resources, materials and mineral waters as well as available financial expenses.

The individual health resorts of Podkarpackie province offer following treatments:

- mineral baths: pearl, carbonic, cold-heat,

- baths using gases: ozone, carbon dioxide,

- mud treatments: peat baths, peat packs, mud pebbles, peat iontophoresis,

- inhalations: group and individual,

- massages: classic, Aquavibron, Hydrojet, Intervac, lymphatic, pneumatic, underwater,

- cryotherapy: wraps, cryochamber,

- electrotherapy: diadynamics, ionophoresis, magnetotherapy, currents Kotza, Tensa, Trabert, electric-water bath, electrostimulation, electroplating, teraplus, 
- light therapy: solux lamp, solaris, Bio-V, sanotherm, laser therapy,

- hydrotherapy: showers, rubbing, wrapping, local or general wraps,

- kinesiotherapy: group and individual,

- paraffin treatments: wraps,

- crenotherapy: drinking cure.

In the Table 4 summary of all treatments performed in 2010-2016 in health resorts and their percentage value in the province and in the whole country was presented.

Tab. 4. Summary of the performed health resorts treatments

Tab. 4. Zestawienie przeprowadzonych zabiegów uzdrowiskowych

\begin{tabular}{|c|l|c|c|c|c|}
\hline No. & Type of treatment & $\begin{array}{c}\text { Number of } \\
\text { treatments in the } \\
\text { Podkarpackie } \\
\text { province }\end{array}$ & $\begin{array}{c}\text { Number of } \\
\text { treatments in } \\
\text { Poland }\end{array}$ & $\begin{array}{c}\text { Percentage of } \\
\text { individual } \\
\text { treatments in the } \\
\text { Podkarpackie } \\
\text { province [\%] }\end{array}$ & $\begin{array}{c}\text { Percentage } \\
\text { in the country } \\
\text { scale [\%] }\end{array}$ \\
\hline 1. & Mineral baths & 1640762 & 20123914 & 6,92 & 8,48 \\
\hline 2. & $\mathrm{CO}_{2}$ baths & 749496 & 7472806 & 3,16 & 3,15 \\
\hline 3. & Mud treatments & 2238154 & 20936110 & 9,44 & 8,82 \\
\hline 4. & Inhalation & 1394252 & 11580232 & 5,88 & 4,88 \\
\hline 5. & Massages & 2349827 & 24076452 & 9,91 & 10,14 \\
\hline 6. & Cryotherapy & 977600 & 10230941 & 4,12 & 4,31 \\
\hline 7. & Electrotherapy & 3033084 & 31069295 & 12,79 & 13,09 \\
\hline 8. & Phototherapy & 1545286 & 17422311 & 6,51 & 7,34 \\
\hline 9. & Water cure & 2012230 & 25760351 & 8,48 & 10,85 \\
\hline 10. & Kinesitherapy & 6491815 & 51329376 & 27,37 & 21,62 \\
\hline 11. & Paraffin treatments & 233671 & 1831991 & 0,99 & 0,77 \\
\hline 12. & $\begin{array}{l}\text { Other healing } \\
\text { treatments }\end{array}$ & 1055097 & 15583675 & 4,45 & 6,56 \\
\hline & & 23721274 & 237417435 & 100,00 & 100,00 \\
\hline
\end{tabular}

In the whole health resort base of the Podkarpackie province, more than 20 million treatments have been performed in the examined time. Most treatments were performed in the kinesitherapy department, then in the electrotherapy and massage department. The lowest classifies treatments are in the field of cryotherapy and therapeutic baths in carbon dioxide. The least was done through paraffin treatments.

\subsection{Municipal infrastructure of health resort communes in the Podkarpackie province}

In the analysis of communal infrastructure development, the rural-urban areas of the Podkarpackie health resorts were taken into account. In the last year of analysis, most people use the water supply network in Horyniec-Zdrój (82\%), 
then in the Solina municipality, in which is located Polańczyk (78\%), Iwonicz Zdrój (56\%) and Rymanow Zdrój (41\%).

The longest water supply network is in the Solina commune, however the largest number of water connections to buildings is in the Rymanów-Zdrój commune. The shortest water supply network has the Iwonicz-Zdrój commune.

Taking into account the degree of sewerage, the most percentage using sewage systems, as much as $97 \%$ occurs in Iwonicz Zdrój, then in Rymanów Zdrój (82\%), Horyniec Zdrój (64\%) and the Solina commune (57\%).

The longest sewerage network and the largest number of connections to buildings are in the Rymanów-Zdrój commune. The shortest sewerage network has the Solina municipality. A bigger degree of sewerage than water supply in Iwonicz Zdrój and Rymanów Zdrój may result from the use of individual sources of water supply.

In turn, almost $94 \%$ of the population uses gas pipelines in the municipalities of Iwonicz Zdrój and Rymanów Zdrój, in the commune of Solina and Horyniec Zdrój there is a small percentage of users of $10,5 \%$ and $0,4 \%$ respectively. The longest active gas network is in the Rymanów-Zdrój commune, and the shortest in commune of Horyniec-Zdrój. Most of the gas recipients have the Rymanów-Zdrój commune, up to 14789 people.

Also the failure rates of the water supply network of examined health resorts were taken into account. It is recommended to assess the condition of the assets and decide when repair, renovation or replacement should be performed according to guidelines presented in ISO 24516-1:2016 [13]. The technical state of water network was assessed in the form of failure rate including number of failures per kilometre per year. In all distinguished health resort communes, the decrease of failure rate of water pipe was observed in comparison to the previous year. The value of failure rate was from $3,09 \mathrm{a}^{-1} \cdot \mathrm{km}^{-1}$ in Iwonicz Zdrój, in other health resorts the value of failure rate indicated much lower values, including Rymanów Zdrój 0,246 $\mathrm{a}^{-1} \cdot \mathrm{km}^{-1}$, Horyniec Zdrój $0,33 \mathrm{a}^{-1} \cdot \mathrm{km}^{-1}$ and the smallest value which equals $0,089 \mathrm{a}^{-1} \cdot \mathrm{km}^{-1}$ was in the Solina commune. According to the recommendations presented in the works $[14,15]$, the failure rate does not exceed $0,1 \mathrm{a}^{-1} \cdot \mathrm{km}^{-1}$ as in case of water network in Solina commune, characterize low failure rate of water network and high reliability, in other cases the average failure rate and reliability can be distinguished with the failure rate in the range from 0,1 to $0,5 \mathrm{a}^{-1} \cdot \mathrm{km}^{-1}$ and the last with high failure rate and low reliability for the failure rate over $0,5 \mathrm{a}^{-1} \cdot \mathrm{km}^{-1}$.

From the communes in which there are places with health resort potential the longest water supply network has the Lubenia commune, in which Lubenia and Straszydle are located, the shortest has the Brzozów commune. The largest number of water supply connections is located in the Dębica commune, and the Lesko commune has the largest water consumption. The longest sewerage network has the Brzozów commune, in the area of which Brzozów and Humniska are located. The shortest sewerage network has the commune of 
Komańcza. Most sewer connections occur in the community Brzozów, and the largest amount of wastewater discharged was reported in the municipality of Dębica. Also it should be mentioned, that sensitive customer, such as disabled or ill people are supplied from public water supply systems in the areas of health resorts. For this reason, the water supply should be characterized by continuity and good protection [16].

\subsection{Indicators of tourist development in health resorts communes}

In order to assess the tourism development of spa communes, basic indicators characterizing its development were determined [17]. The basic indicator used to assess tourist development of municipalities is the Defert's index, or else the assessment of tourist intensity of the area, determined as the quotient of the number of tourists using accommodation per the distinguished area, in $\mathrm{km}^{2}$. The areas on which the Defert's index exceeded 1000 are considered to be a well-developed tourist area. Only the Polańczyk health resort fulfills this requirement. In turn, the assessment of the intensity of tourist traffic can be presented by means of the Schneider's index determined by the quotient of the number of tourists using accommodation by a fixed number of area inhabitants. According to the Schneider's index, the town with a score of 500 is a well-developed tourist destination. Among the Podkarpackie health resorts, Iwonicz-Zdrój and Polańczyk meet this requirement. The assessment of the accommodation base density has been presented using the Baretje-Defert's indicator, calculated as the number of tourist beds to the number of permanent residents of the area. The Baretje-Defert's indicator showed that Horyniec-Zdrój and Rymanów-Zdrój are towns with little tourist traffic, Iwonicz-Zdrój is a town with a dominant tourist function, and Polańczyk is a big tourist center. However, the assessment of accommodation density has been determined as an indicator of the accommodation base density, as the ratio of the number of tourist accommodation places by the area expressed in $\mathrm{km}^{2}$. The largest density of accommodation is in health resorts is in Polańczyk, while the smallest is in Horyniec-Zdrój.

\section{Conclusions}

The most promising health resort is located in the Polańczyk. Despite the fact that it is the youngest health resort in Podkarpackie, it has the greatest potential and develops fastest, which was emphasized by the tourist development indicators of this city. The Solina commune has the largest increase in the water supply network. In addition, Polańczyk offers a wide range of spa treatments in a variety of forms. Its advantage is the brevity of the entire base, the distance between accommodation bases and buildings offering treatments is small. There are only 5 sanatoria on its site, of which only one is solely a lodging base. In the 
remaining four, some of the treatments can be used without leaving the sanatorium.

The second most growing center of the health resort is Iwonicz-Zdrój, which according to the tourist intensity ratio is a place with dominant tourist function. In the municipality of Iwonicz-Zdrój, the smallest increase in the water supply network was calculated. In addition, as in Polanczyk, it has a wide range of treatments in as many as eight centers. In Iwonicz-Zdrój there are five sanatoria, of which only two offer health resort treatments. In addition, there is also a hospital, a health resort center and a mineral water pump room. The successive development of the spa is also conditioned by spa facilities outside the Uzdrowisko Iwonicz, of which there are six objects. Thanks to them, more accommodation and treatment rooms are available for patients.

The third is the Rymanów-Zdrój health resort. According to the intensity of tourist traffic, Rymanów-Zdrój is a city with a low tourist traffic. The spa has a very wide range of spa treatments, with 10 spa centers in its area, of which five are only accommodation bases, two are combined centers (lodging bases and treatment rooms), and the remaining three are only facilities used to perform treatments.

Horyniec-Zdrój is in the last place in terms of tourist attractiveness and the offer of health resort treatments. According to the Baretje-Defert's index, it is a place with little tourist traffic. In comparison to other spas, Horyniec-Zdrój offers the smallest range of health resort treatments. It has five spa facilities, four in the area of A1 health resort area protection and one facility in the A2 area. Some of them, are only the accommodation base in the form of sanatoriums. Only sanatorium Bajka offers both accommodation and spa treatments. The other objects are only places offering health resort treatments. The dispersion of these objects in two zones and their number significantly affect the reduced interest in the base and its development.

Health resorts of the Podkarpackie region are gradually developing and maintaining a high level of services in the field of health resort treatment. The number of patients increases every year, increasing for the Poles and foreign guests. The offer of tourist facilities as well as accommodation facilities are also growing. The number of treatments is gradually increasing. It was stated that before the province would implement the opening of centers in places with health resorts possibilities, first of all, care should be taken for existing health resorts bases to further diversify the offer, modernize the centers, so that they would attract more potential clients.

\section{References}

[1] Rak J.: O możliwościach wykorzystania wód mineralnych w profilaktyce zdrowotnej (The possibilities of using mineral water in health prevention), Gaz, Woda i Technika Sanitarna, nr 7-8, 2010, pp. 28-30. 
[2] Rak J., Pietrucha-Urbanik K.: Nowe - stare możliwości uzdrowiskowe województwa podkarpackiego (New - old health resort possibilities Podkarpackie Province). Walory ekologiczne i turystyczne północnej części Euroregionu Karpackiego 2009, pp. 293-301.

[3] Rak J., Pietrucha-Urbanik K.: O złożach i źródłach wód uzdrowiskowych (About deposits and sources of health resort waters), Technologia wody nr 2/2010, 2010, pp. 70-74.

[4] Rak J.: Balneotechnika. Terapie uzdrowiskowe (Balneo-technique. Health resort therapies). Oficyna Wydawnicza Politechniki Rzeszowskiej, Rzeszów 2011.

[5] Rak J., Pietrucha-Urbanik K., Boryczko K.: Balneotechnika. Wody mineralne (Balneo-technique. Mineral water). Oficyna Wydawnicza Politechniki Rzeszowskiej, Rzeszów 2013.

[6] Rak J., Tchórzewska-Cieślak B.: Podkarpackie wody mineralne i lecznicze jako czynnik hydroterapii w turystyce (Subcarpathian mineral and therapeutic waters as a hydrotherapy factor in tourism). Turystyka w parkach krajobrazowych, Wydawnictwo Uniwersytetu Rzeszowskiego, Rzeszów 2009, pp. 155-170.

[7] Rak R. J., Tchórzewska-Cieślak B., Pietrucha K.: Balneotechnika. Walory uzdrowiskowe (Balneotechnique. Health resort qualities). Oficyna Wydawnicza Politechniki Rzeszowskiej, Rzeszów 2010.

[8] Central Statistical Office. Analytical Platform. Analyses and Decisions Support System. Knowledge Databases, Warsaw 1995-2016.

[9] Central Statistical Office. Local Data Bank, Warsaw 1995-2016.

[10] www.uzdrowisko-iwonicz.com.pl, Strona Uzdrowiska Iwonicz-Zdrój, (access: 10.11.2016).

[11] Kruczek Z., Weseli A.: Uzdrowiska karpackie (Carpathian Health resorts). KAW, Kraków 1987.

[12] Sielicka J.: Informator - atlas uzdrowisk polskich (Catalogue - atlas of Polish health resorts). Izba Gospodarcza - Uzdrowiska Polskie, Warszawa 2005.

[13] ISO 24516-1:2016. Guidelines for the management of assets of water supply and wastewater systems - Part 1: Drinking water distribution networks.

[14] Kwietniewski M.: Awaryjność infrastruktury wodociągowej i kanalizacyjnej w Polsce w świetle badań eksploatacyjnych (Failure of water supply and wastewater infrastructure in Poland based on the field tests), In: XXV Scientific-Technical Conference, Międzyzdroje, Poland, May 24-27, 2011, pp. 12-140.

[15] Rak J.: Podstawy bezpieczeństwa systemów zaopatrzenia w wodę (Issues of water supply system safety). Committee of Environmental Engineering Sciences, Lublin, Poland. 2005.

[16] Rak J., Pietrucha-Urbanik K.: New directions for the protection and evolution of water supply systems - smart water supply. Czasopismo Inżynierii Lądowej, Środowiska i Architektury - Journal of Civil Engineering, Environment And Architecture, JCEEA, z. 62, nr 3/I/2015, pp. 365-373. DOI:10.7862/rb.2015.121.

[17] Szromek A.: Wskaźniki funkcji turystycznej i ich współzależność z innymi wskaźnikami ekonomicznymi na przykładzie polskiej gospodarki w latach 20002010 (Indicators of tourist function and their correlation with other economic indicators on the example of polish economy in 2000-2010). Prace naukowe Uniwersytety Ekonomicznego we Wrocławiu 2012, nr 304, pp. 336-349. 


\section{PODEJŚCIE DO ANALIZY STANU BAZY UZDROWISKOWEJ W WOJEWÓDZTWIE PODKARPACKIM}

W pracy przedstawiono analizę baz uzdrowiskowych znajdujących się na terenie województwa podkarpackiego. Wykonano charakterystykę miejscowości Horyniec-Zdrój, Iwonicz-Zdrój, Polańczyk i Rymanów-Zdrój zawierającą rys historyczny, opis klimatu, gleb i wody, strefy ochrony uzdrowiskowej, dostępne wody mineralne i surowce lecznicze oraz opis przeprowadzanych zabiegów. Analizę wykonano na podstawie danych statystycznych dotyczących liczby działających ośrodków, liczby kuracjuszy, liczby wykonanych zabiegów oraz infrastruktury komunalnej w latach 1995-2016. Analizę sporządzoną na podstawie analizy danych statystycznych zebranych przez Główny Urząd Statystyczny. Ponadto dla tych miejscowości uzdrowiskowych obliczono wskaźniki rozwoju infrastruktury wodociągowej oraz wskaźniki rozwoju turystycznego. Praca ma na celu analizę wszystkich baz uzdrowiskowych na terenie województwa podkarpackiego oraz określenie, które $\mathrm{z}$ uzdrowisk rozwija się najlepiej, gdzie oferowane są poszczególne zabiegi, a także jakie naturalne surowce lecznicze spowodowały, że akurat te miejscowości świadczą zabiegi balneologiczne.

Słowa kluczowe: uzdrowisko, charakterystyka uzdrowisk, infrastruktura komunalna, wskaźniki rozwoju turystycznego

Przestano do redakcji: 14.09.2017 $r$.

Przyjęto do druku: 15.12.2017 r. 